\title{
What Makes for Effective Labor Representation on Pension Boards?
}

\author{
Johanna Weststar, University of Toronto (now at Western University) \\ Anil Verma, University of Toronto
}

A fully edited, peer-reviewed version of this paper was first published in the Labor Studies Journal and should be cited as follows:

Weststar, J. \& Verma, A. (2007). What makes for effective labor representation on pension boards? Labor Studies Journal, 32(4), 382-4101.

\section{Acknowledgements:}

Research reported in this paper is part of a larger project, 'Pensions at Work', spearheaded by Jack Quarter and Isla Carmichael from the Ontario Institute for Studies in Education, University of Toronto (OISE/UT) and funded by the Social Science and Humanities Research Council of Canada. For more information on the project please visit: www.pensionsatwork.ca. We would like to thank Jack, Isla and members of the Pensions at Work Union Reference Group for assistance and advice in the early stages of this research, and Charlotte Yates and three anonymous reviewers for helpful comments on earlier drafts of this paper.

What Makes for Effective Labor Representation on Pension Boards?

\section{Introduction and Context}


Unions can leverage worker's capital through various strategies such as: producer cooperatives, worker ownership of shares in their own company, union funds for national or regional economic development, and influence on the investment of worker pension and savings funds (Wheeler, 2004: 88). In particular the governance of pension funds has received considerable attention in recent years (Northrup, Northrup, Bellante and Raisian, 1981; Johnson, Harwood and Heldman, 1981; Ghilarducci, 1992; Quarter, 1995; CUPE, 1996, 2005; Carmichael, 1998; Fung, Hebb and Rogers, 2001; Quarter, Carmichael, Sousa and Elgie, 2001). The interest in pension funds stems from several factors. For one, due to their size, pension funds can have a powerful impact on financial markets (Drucker, 1976; Deaton, 1989). Worldwide pension assets are valued at $\$ 11$ trillion (Anand, 2000) with a recent Freshfields report estimating United States and United Kingdom pension funds at \$7.4 trillion (2005). Canadian pension assets have been estimated at $\$ 600$ billion (CLBC, 2002). Pension funds also represent an important opportunity for unions to support the growing movement towards a proactive investment strategy that takes into account environmental, social and governance issues (Ghilarducci, 1992; Fung, Hebb and Rogers, 2001; Freshfields, 2005).

In a time of union decline and debate over their relevance, greater activism in pension funds may also be a means to union renewal. Referring to the labor movement in the United States, Wheeler (2004) suggests that use of worker capital to influence corporate strategy toward socially responsible outcomes may result in much needed positive public relations for unions (see also Bennett and Johnson, 1981). Such a focus also broadens the labor agenda to larger social and economic arenas which increases opportunities for visibility and coalition building. Participation in governance is also of immediate self-interest to unions because it may provide additional security to plan beneficiaries (Quarter, 1995; Quarter, et al. 2001). 
One important aspect of the labor movement's involvement in pension funds is the appointment of labor or member representatives to pension trustee boards or committees ${ }^{1}$ (Carmichael and Quarter, 2003). In 1998 it was estimated that one-third of all pension assets in Canada fell under some form of joint-trusteeship (Falconer, 1999) and that 18 of the top 23 unions had won or were in the process of winning some form of joint-trusteeship (as cited in Carmichael and Quarter, 2003). Similar moves toward employee representation are occurring in other industrialized nations as well. For example, using survey data from 1990-2000, Hess (2005) reported that one-third of the trustees on public pension funds in the United States were member-elected (see also Schuller and Hyman, 1983a, 1983b and 1984; Gribben and Faruk, 2004; Gribben and Olsen, 2002 for studies of the United Kingdom, and Fung, et al., 2001 and Wheeler, 2004 for discussions of the United States).

A key debate in the management of pension fund investment is whether the fiduciary mandate stipulates pure profit maximization based only on financial indicators or whether financial returns and the best interests of beneficiaries allow or demand the consideration of environmental, social and corporate governance issues (Freshfields, 2005). This latter stakeholder perspective acknowledges a firm's financial obligations to its shareholders, but underscores the accompanying obligations to the firm's other stakeholders: their workers, customers, communities and the environment (Clark, 2000; Chapman, 2002; Hebb and Jackson, 2002). Despite the growing interest and acceptance of extra-financial investment considerations and the increase of labor representation on pension boards of trustees, there is mixed support for this approach both in the financial community and the labor movement. Many finance professionals reject and discourage a stakeholder approach to pension investment and

\footnotetext{
${ }^{1}$ Union representatives are also called member representatives, labor trustees, union trustees, plan participant representatives and sit on pension boards, committees and advisory committees. For brevity, we will use labor trustees and pension boards to denote all of these possibilities unless otherwise stated.
} 
also discount the value of labor trustees at the board table. Trade unions face several choices in pension fund governance: whether to engage in pension governance through labor representation at all, whether to maintain the status quo of pension investment through traditional interpretations of fiduciary duty, or whether to adopt varying degrees of a stakeholder perspective (see Weststar and Verma, forthcoming).

The premise for this study rests on the assumption that unless unions' goals for pension involvement are clearly articulated and they initiate a process by which they can develop requisite leadership, it will be difficult for unions and labor trustees to effectively participate on pension boards and achieve strategic goals at any level. Preliminary studies of labor trustees show that they face considerable barriers as they attempt to fulfill their new roles and impact the decisions of the pension bodies on which they serve (Schuller and Hyman, 1984; Deaton, 1989; Carmichael, 2003). Exacerbating this, many unions have yet to express a comprehensive and proactive policy on their role in pension fund governance. As indicated above, while some unions believe that they must push for greater labor participation in pension issues, others stay clear of them. Others are less clear on a mandate to give to their representative(s) on the pension board. Since their goals in pension governance remain unclear, most unions do not appear to have a formal process to identify and develop their own talent in this area.

Given this environment, this paper seeks to identify the factors that help labor trustees become effective pension board members in the Canadian context. We combine analysis of existing literature with data gathered through interviews with labor trustees to develop a model that links institutional characteristics of the board and union strategic choices to trustee development needs. We propose that this model can be used to aid the integration, participation and overall effectiveness of labor trustees given particular trustee or union strategic goals. The 
following section presents a brief overview of the institutional context for pensions that frames many of the ideological debates and challenges that face labor trustees. This context is largely described for Canada, however, common law countries such as the United States, United Kingdom and Australia have a similar context. Next, we outline the research method and discuss the experiences of labor trustees as exemplified by our interview findings and existing literature. Last, we present our model of trustee development and offer implications of our study and avenues for future research.

\section{Key Legislation and Associated Debates}

In Canada workers can receive pension income from government-sponsored programs as well as employer-sponsored pension plans that are based on employer and employee contributions. Employer-sponsored plans in Canada are quite varied. Statistics from January, 2000 show 1,276 plans covering 2.4 million federal, provincial and municipal government employees and 14,281 individual or multi-employer plans covering 2.6 million commercial, industrial and other private sector workers (as cited in Greenan, 2003). More recently the Certified General Accountants of Canada (CGA-Canada) conducted a study using 847 plans from the MERCER Pension Database. They report that of the 746 plans from this sample that operate in the private sector, 42 per cent cover unionized workers. They did not include a breakdown by unionization for the remaining 101 plans deemed non-private sector, but the majority of these would assumedly be large public sector plans covering unionized workers (CGA-Canada, 2004).

With the exception of those employees and industries that fall under jurisdictional authority of the federal government (i.e., Crown Corporations, banks, railways and employees in 
the Yukon, Nunavut and the North West Territories), pension funds fall under provincial jurisdiction and specific pension standards legislation. Two components of the pension standards legislation are particularly important for union involvement in pension issues. The guidelines for plan administration impact the composition of the pension Board of Trustees while the principles of prudence set the tone for investment strategy. Though each province has separate pension legislation, the clauses regarding pension administration and prudence are substantively similar. This is also the case in other countries with common law jurisdiction (i.e., US, UK and Australia). For example, the Employee Retirement Income Security Act (ERISA) in the US covers private pension plans and outlines the naming of fiduciaries (section 402) and establishes the "prudent man" standard of care (section 404) which is much the same as provided in Canadian legislation (Freshfields, 2005; see also BenefitsLink, 2006).

\section{Pension Administration}

Generally pension standards legislation includes a list of possible plan administrators: the employer, a pension committee comprised of employer representatives and/or members of the plan, the insurance company guaranteeing the benefits provided under the plan, or a board of trustees of either employer or member representatives or both (Greenan, 2003). Some pension plans, particularly those operated and/or sponsored solely by the employer or government also include advisory committees as part of their governance structure. Advocacy for such advisory committees is increasing as the concern over pension governance rises (CGA-Canada). The result is a wide array of governance structures across pension funds with and without member or labor representation. A summary of the most common models is presented in Table 1 and discussed below. 
For those unions interested in obtaining representation in pension governance, jointtrusteeship is the premiere goal and unions such as those associated with the Ontario Public Service Employees' Union Trust (OP Trust), the Hospitals of Ontario Occupational Pension Plan (HOOPP) and the Colleges of Applied Arts and Technology (CAAT) Pension Plan have achieved the most equal representation and the most direct selection control of their representatives (see \#2 and \#3 in Table 1). Some unions, primarily those in the building trades have a different model, but one that also achieves high levels of control over pension funds. In these industries unions act as the stable force because members work with multiple employers. For this reason, the unions have sole trusteeship of pension plans into which the employers contribute funds. A financial consulting firm is typically appointed to administer the plan (see \#1). Another model of note is listed as \#7 where Quebec legislation stipulates that there be a labor or membership representation on the pension committee that administers the plan (Greenan, 2003). In practice this often results in pension committees comprised of two plan beneficiaries (one active and one retiree), one member independent of both the employer and the beneficiaries, and five management representatives $\left(\mathrm{PTI}_{1} 9^{2}\right)$. The Ontario Teacher's Pension Plan (listed as \#5) is also worth separate mention as it demonstrates that union representatives are not necessarily union members. In this case, it is not four teachers who sit on the board with four employer representatives, but four teacher representatives typically selected from the financial community (Ontario Teachers', 2005). Some unions, particularly private sector unions such as the Canadian Autoworkers' Union (CAW), show less interest in achieving union representation on pension boards (\#11) (discussed below).

\section{Prudence}

\footnotetext{
${ }^{2}$ The codes PTI01-PTI20 reference interviews with labour trustees. See Appendix 1 for a profile of interviewees.
} 
The notion of prudence is also important for labor trustees and contains two principles: the prudent portfolio and the prudent person. The prudent portfolio stipulates that a given investment be analyzed with respect to how it affects the risk and return of the pension portfolio as a whole and not as a stand-alone investment. The prudent person stipulates that the plan administrator and its agents "exercise the care, diligence and skill in the investment of the pension fund that a person of ordinary prudence would exercise in dealing with the property of another person." (Greenan, 2003: 200) Though these principles originated out of the desire to instill caution in trustees who generally "carry the responsibility of ownership without the ownership itself," (Carmichael, 2003: 53) traditional interpretations of prudence, or fiduciary responsibility, have acted as a barrier to alternative investment and governance models.

Traditional models of pension governance focus on rate of return often to the exclusion of extra-financial factors such as the environment, corporate ethics or social impact. As representatives of unions, which are social and political actors, labor trustees are in a position to support the growing stakeholder perspective on investment (Clark, 2000; Chapman, 2002; Hebb and Jackson, 2002) that is not readily accepted or that is rejected outright under narrow interpretations of prudence and fiduciary duty. Counter-arguments are emerging that state that fiduciary duty does not preclude pension trustees (labor or otherwise) from investing based extra-financial criteria provided that such decisions do not negatively affect the pension plan or its beneficiaries (see Yaron, 2001, 2003 and 2004; Carmichael, 2003; Freshfields, 2005; Milevsky, Aziz, Goss, Thomson and Wheeler, 2005). These counter-arguments are becoming more prevalent and sophisticated; however, as will be elaborated later, labor trustees who wish to adopt a stakeholder perspective still face considerable difficulty in overcoming the traditional fiduciary duty argument. 
Within the pension environment, the role of unions and their representatives involves making three inter-related strategic decisions. First, unions must decide if they want a seat on the board. If yes, they must work to obtain that seat, whether through collective bargaining, government intervention or other means, and choose to fill it with either a labor trustee or a professional hired for the purpose. Second, unions must decide how the labor trustee will acquire the financial background necessary to actively participate in investment decisions to protect the pensions of fund beneficiaries. Third, unions must decide if they want their trustees to push for the application alternative investment policies. Such policies could consider environmental practices, place screens on enterprises that seek to privatize public services and focus on investments that benefit communities through encouraged development of local business or promotion of affordable housing. Investment policy could also consider labor relations and employment standards such that pension fund investment could be used strategically either against recalcitrant employers or toward employers with labor-friendly policies and behaviours (Fung, Hebb and Rogers, 2001; Grayson and Hodges, 2002; Hannah, 2003; Wheeler and Thomson, 2004; Manley, Hebb and Jackson, 2005; Hebb and Jackson, 2002).

When considering their first strategic decision, whether or not to participate in pension governance, unions face a choice somewhat akin to union participation in decision-making along with management. In the research literature, it is generally well recognized that in considering this opportunity, unions face a difficult choice. Participating in managerial decision-making can be a double-edged sword. While it may give the union greater say in workplace matters it also prevents the union from acting independently of management. Rank-and-file members may view union leadership as becoming closer to management than to their own interests. At a practical level, this could lead to an ouster of the leadership or at the very least it would create 
tensions between the union leadership and union members (Eaton and Rubinstein, 2006; Eaton and Schurman 2006). Other writers on the topic have suggested that it will be theoretically difficult for unions to represent worker interests if they adopt a more managerial view of the organization (Parker and Slaughter 1988; Katz 1988; MacDuffie 1995; Eaton and Schurman 1996). All these arguments are also applicable to the union decision to seek a seat at the pension board. These problems notwithstanding, there has been an "expansion of local union involvement in firm governance and management" that challenges "the managerial prerogatives established by the New Deal industrial relations system" (Rubinstein 2001: 411) and union involvement in pension plan governance can be seen as a subset of this expansion.

A few unions such as the Canadian Autoworkers' Union (CAW) have decided to maintain the traditional demarcation between labor and management on pension plan issues. In remarks to the IQPC Canada Conference on Pension Investment \& Governance, Jo-Ann Hannah, a CAW staffer, summarized the CAW's lack of enthusiasm in participating in pension fund governance. For one, public sector unions generally have one or two large pension plans where private sector unions have hundreds of plans. The cost of providing training and on-going support to labor trustees in these cases is prohibitive. Second, private sector unions are able to collectively bargain for pension improvement or change where public sector unions are not. Third, the CAW view is that unions should not buy into the neo-liberal ideology that the market is central to the democratic process. They argue that unions should bargain for increased pensions and benefits through traditional arms length processes and fight the battle of social responsibility and worker's rights in other forums (Hannah, 2003; see also Stanford, 1999).

In order to successfully expand their role in governance and management, unions must carefully consider, prepare for and address the changing risks and required resources associated 
with representing their membership in new ways (Rubinstein, 2001; Eaton and Rubinstein, 2006). For example, the Ontario Teachers' Federation received negative backlash from many unions and pension activists in response to the United Food and Commercial Workers' Union (UFCW) strike against Maple Leaf Foods in 1997-1998. As major shareholders in Maple Leaf Foods the Ontario Teachers' Pension Plan Board did nothing while members of UFCW across Canada fought to resist concessions (many against benefits packages that did not include a pension plan) and job loss. Critics argued that the Teachers should have leveraged their shareholder power to pressured Maple Leaf Foods to work for a fair contract. This type of action is a completely new approach for unions and their members and raises a host of questions about the use of pension fund power. For these reasons, unions embarking on pension involvement must enter this new arena with an understanding of the risks involved and with a clear and articulated assessment of their purpose. In direct relation to the experiences that local union leaders face as they experiment with co-management techniques (Rubinstein, 2001) labor trustees must not be caught unprepared in responding to concerns within the labor community. Labor trustees must be provided with the necessary resources by their unions if they are to succeed in achieving labor's mission. This study is an attempt to identify the resources that labor trustees need at personal and institutional levels.

These resources are important for the second and third decisions that unions must make regarding the training and agenda of the labor trustee. By getting to the second level (obtaining and seat and basic financial training), unions and their labor trustees can ensure stronger financial health of their pension funds through increased diligence and attention to investment matters. By pushing through to the third level of alternative investment policy unions and their labor trustees can ensure the protection and growth of their pension monies, but they can also 
benefit their constituencies, their fellow workers in the broader labor movement, and the social, economic and environmental health of their greater communities. However, and as this research will show, many unions are at the first stage and are only beginning to realize the potential of pension board representation. Those unions that have achieved a seat have largely stalemated at the second stage with only a few achieving some impact on the governance of pensions in terms of socially responsible investment (SRI), economically targeted investment (ETI) or the leverage of shareholder proxy votes to promote corporate good governance and other outcomes. To achieve these ends labor trustees must be able to challenge the traditional models of pension investment and governance. Otherwise, they risk becoming token members of the board.

\section{Research Method}

Several sources of data were used for this exploratory research. Primarily, semistructured interviews were conducted with nineteen labor trustees on pension boards and one labor representative on a pension fund advisory committee. On several occasions the interviews were recorded with an audio recorder, although some trustees preferred that we take notes only. The interview transcripts were analyzed for common themes and key individual or unique comments. As the pension trustee community is small, interviewees were assured anonymity in any publication of our results and their names are not reported nor associated with their union and pension plan affiliation.

A copy of the interview protocol is included as Appendix 1, though it should be noted that occasional deviation occurred in individual cases to accommodate specific situations. The interview questions consist of ten open-ended questions that roughly follow the induction of the individual as a trustee and the steps they go through in becoming effectively integrated into the 
board. Since our purpose in interviewing them was to learn more about the underlying problems and prospects for trustee effectiveness the questions were deliberately written to be exploratory. The basic idea here was to encourage the interviewee to open up a dialogue and talk through their experiences. The intent was to learn as much as possible about the processes so that later we could identify a more structured process to describe the trustee induction, integration and development.

The sample used in this study is not entirely representative. Indeed, through the course of this research and related work, we identified many factors that made it difficult to obtain a large representative sample of labor trustees. There is no comprehensive and published listing of labor trustees in Canada. Some plans have websites with information about the governance structure. Of these sites most indicate the number of labor trustees on the board and some include a listing of names and/or union affiliation. A small number list full contact details. When contacted, most pension plan staff were reluctant to disclose contact information. Unions seem somewhat more willing, although some union staff were unsure of the identity of their pension trustees or who might have such information. We relied, therefore, on our personal networks and those of the Pensions at Work Research Network (PAW, 2004). This initial search led us to interview eight very experienced trustees, most of whom were also high profile pension activists. These interviews formed the core sample of this study because our informants were in a position to comment on their many years of trusteeship and their evolving needs. Following these interviews, twelve additional labor trustees were contacted and interviewed. As with the first, this second wave was largely a convenience sample although greater attention was paid to achieving a balanced slate of participants in terms of gender, visible minority status, board tenure, geographical region, and plan sector. 
The resulting sample represents four funds based in Ontario, one in Quebec, four from the Atlantic provinces, eight from the Western provinces, and three that are under the federal jurisdiction. They are predominately public sector funds (fourteen of the twenty). Most interviewees are white men with four women and two racial minorities represented. Tenure as a trustee ranges from several months to well over ten years, All interviewees are over the age of thirty-five and most have had considerable seniority in their occupations and unions (see Appendix 2 for interviewee profiles). Private sector funds are underrepresented as are Quebecbased funds. There is no representation of members of the financial community who are appointed by unions to act as labor trustees (i.e., labor trustees from the Ontario Teachers' Plan) as they represent a group that is markedly different from trustees who are union staff or rank and file union members.

Information was also gathered through meetings with a union reference group that was brought together under the auspices of the Pensions at Work project (PAW, 2004). Contact was made with this research group on three occasions where aspects of the study and pension life were discussed and verified. In what follows we draw on the voices of these labor trustees and integrate their experiences with past research on union involvement in pension governance, labor trustees and member representatives. Through these sources we develop a model of labor trustee representation on pension boards that follows the logical sequence of recruitment and selection, training and development and accountability. As such this research represents an attempt to ground some of the common themes and points of controversy in labor trustee experiences and present a framework for a better understanding of the process in the hope that this would lead to more effective representation of labor interests on pension boards (Glaser and Strauss, 1967). 
This work is also important to any large sample survey of trustees that can be undertaken in the future (Rubinstein, 2001).

\section{The Life of a Labor Trustee: Previous Literature and Interview Data}

\section{Job Demands \& Steep Learning Curve}

The actual tasks in which labor trustees are engaged, the compensation they receive for their role and logistics such as term length and meeting frequency varied widely among our interviewees. However, they all spoke of the binder that they receive only a few days prior to the board meeting and typically hold up their fingers to indicate its one to two inch thickness. One trustee's comments reflect the general sentiment, "It takes a full day just to figure out what you understand and what you don't, let alone learn what you don't." (PTI04) Once in the meeting the binder is discussed cover to cover often at a rapid pace that assumes complete understanding. In the midst of these discussions the trustees are required to quickly vote on decisions that are based on the binder contents and may concern the allocation of millions of dollars (Post, 2005). All interviewees felt that they could ask questions during the meeting, but some felt that this slowed down the proceedings and caused annoyance (PTI04; PTI08). The short notice of the binder delivery precludes attempts to contact other labor trustees or activate support networks to gain knowledge or to solidify a particular response or stance on an issue.

In addition to the meeting preparation that occurs for two or three days beforehand, trustees spend time in the meetings (often 4-15 meetings or days per year) and several trustees reported spending more than 20 extra hours in general learning time per meeting (PTI01; PTI07; PTI08; PTI13; PTI16). This time is often not recognized in the compensation schemes for labor trustees who are typically paid for work missed for meeting time only. As a result many trustees 
may not have the time or the will to engage in extra learning or networking (PTI14; PTI15). In this way their potential as a strong labor representative is hampered because they do not attain the knowledge or perspective necessary to be a full participant. Interviewees told us that they must devote a considerable amount of their personal time to ensure success in their role and that they often bring leadership or union activist experience and a social consciousness to their position as a trustee. These experiences and the characteristics such as confidence, willingness to learn and ability to work in challenging environments that were developed through these experiences allowed the trustees in our sample to feel that they were effective labour representatives.

\section{Recruitment and Selection}

The selection procedures for labor trustees vary greatly, in part due to the different governance models previously outlined in Table 1. Labor trustees or their representatives can be appointed by the union from outside of the union, recommended by the union but officially appointed by the government or the plan itself, elected by plan participants, or selected by the union. The internal process for identifying talent to serve in this role is similar to the way unions select other functional specialists. It is a process of nomination by the union leadership. Even though in some unions the nominated person must then face an election, the nomination by the union executive is generally authoritative in securing the job for that person. As a result unions tend to select or recommend union staff, union activists or elected union officials for the role of pension trustee. One trustee reported knowing nothing about pensions before he started, but he feels that he had a lot of other skills, such as leadership ability, confidence, union experience, the gift of persuasion, and public speaking skills that made him a good trustee (PTI17). The sense that there was more to the job of labor trustee than the financial knowledge was shared by all 
interviewees and many believed that this, with proper training, could be learned 'on-the-job.' What they deemed more important from the outset was strong leadership capability and a solid union perspective.

Despite the sentiments above, all interviewees agreed that the learning curve was incredibly steep and required a sustained and concerted effort to overcome. As one trustee stated, "Regardless of their background very few people are well prepared for the educational demands of being a trustee." (PTI07) As such the traditional nomination process used by unions could be augmented by a more formal selection approach. Human resource management professionals recommend that formal selection should include the following steps: a job description, posting the job description to recruit a pool of qualified talent and then select the person for the job using validated methods. Some trustees in our sample did face more formalized systems consisting of competency tests, statements of interest and interviews (PTI02; PTI03). However, this level of formality may not suit the political culture of unions and an integrated approach may be more suitable.

An optimal blending of the two approaches can be done in a variety of ways. In our sample several trustees were union staff members of pensions and benefits committees while another was selected because of her knowledge about pensions on a policy level. A more deliberate approach (suggested by a member of the Pensions at Work Union Reference Group) would be to identify a pool of plan members, either by interest or ability or both, and train them in pension issues. When a labour trustee position becomes available the new trustee would be formally selected or elected from this pool. The ultimate formality of the recruitment and selection process is one of debate within unions as each approach raises different issues with respect to ideology and financial and temporal resources. This matter will also require more 
research as to whether trustees who begin their role with a more concrete background are more effective than those who do not.

\section{Knowledge and Ability Acquisition: Training and Social Networks}

According to Schuller and Hyman (1984: 63), labor trustees generally lack the personal and organizational resources of "formal or informal expertise and the breadth and depth of experience, whether this is accumulated inside or outside the pension world." Very little formal training is provided to labor trustees either from the employer, fund, or the union and very few enter their position with sufficient financial savvy (Schuller and Hyman, 1983b, see also Myners, 2001). As well trustees are reported to have few sources of advice independent of the fund. This dependence on the inside sources further reduces the possibility of developing external social networks and other supports for independent learning.

\section{Existing Training}

Our interviews and feedback from pension conferences suggest that traditional training in pension issues does exist, but it is often not adequate in meeting the needs of labor trustees (see also Hebb and Jackson, 2002). Labor trustees are perceived as disseminators of information by the fund managers (and often themselves) as opposed to active participants in deciding investment policy, monitoring fund performance and appointing fund advisors (Schuller and Hyman, 1983b). Fund managers, advisors and the financial community are reported to exhibit a paternalistic attitude toward labor trustees and what training is provided is largely offered by the financial community and does not substantially question traditional approaches, ideologies and perspectives (Carmichael and Quarter, 2003).

One interviewee received no training when he first joined a pension advisory committee. It was only after the fund administrators realized that there was a legal responsibility for the 
actions of the advisory committee that the fund sponsored some training programs. However, these training programs were not seen as sufficient by the labor representatives (PTI12). Labor trustees describe courses that are short and introductory. They are replete with jargon and are often provided through a finance or business lens and rarely deviate from, let alone question traditional pension governance (PTI01; PTI02; PTI13; PTI17). As well, these courses typically cater to pension trustees or board members in general and do not address some of the needs specific to labor trustees such as reconciling their role or bringing forth alternative perspectives.

Interviewees also attend pension trustee conferences, but some described them as “industry gab fests" where "trustees get schmoozed and further indoctrinated." (PTI01) In addition to educational programming that may be sponsored by the pension fund, union or employer, trustees also take courses on their own initiative. These include courses to earn their Chartered Financial Analyst (CFA) designation or Canadian Securities courses (PTI01; PTI17) that cover investment and finance issues beyond pensions and are also from a traditional finance perspective. In line with these findings and previous research (Hebb and Jackson, 2002), unions and education providers are beginning to develop on-going training specific to labour trustees on pension boards at the introductory and advanced level [i.e., Canadian Union of Public Employees (CUPE), Shareholder Association for Research and Education (SHARE), Manitoba Centre for Labour Capital, Pensions at Work, and the Fédération des Travailleurs du Québec (FTQ)].

\section{Training Needed}

The new programming mentioned above attempts to provide basic knowledge for trustees in areas such as accounting, investing and actuarial knowledge; however, there are other areas where gaps exist in the traditional focus of training currently available. One trustee explained that there are two steps to conquering the large learning curve. The first step is to achieve the 
"technical proficiency of the financial lingo, how the financial industry operates, how pensions operate..." The second step is to develop critical thinking and alternative viewpoints and includes issues of SRI, ETI, proxy voting, and other labor agendas (PTI01). As this trustee further emphasized, "an educated trustee is not necessarily a critical trustee," but the reality of pension issues is that trustees barely achieve step one let alone proceed to the next level where they can start exercising their position and influencing the board (PTI01). Other trustees corroborated this difficulty stating, "It took two years just to get up to speed and start" (PTI02) and, "What do union people know about stocks and bonds? It is another universe...It's a very very very steep learning curve. I've never had such a steep learning curve. And it is always there." (PTI02) Such sentiments represent a particular problem for the effectiveness of labor trustees with short tenure on the board. Typically the term of appointment is three years; though many trustees serve multiple terms if subsequent appointment decisions or elections are favorable. The median tenure for our sample is 3.5 years while the mean tenure is 6 years. The interviewees seemed content to attend traditional finance courses as an introductory step, but they agreed that it was necessary to follow-up with a structured and on-going system specific to labor trustees as they become more experienced and begin tackling new issues. Trustees also agreed that more detailed books on pension issues from a labor perspective and 'how-to' manuals or success stories would be useful resources. Also important to labor trustees is training that will provide the opportunity to think about pension issues critically and from a new vantage point. As several interviewees agreed, providing labor trustees with the ability to argue confidently and convincingly from a labor perspective is a critical need (PTI04; PTI16; PTI17). Examples include new interpretations of the prudence principle or the concept of the triple bottom line (social, environment and financial) to advocate for shareholder activism, proxy 
voting and socially responsible investment (see Ambachtsheer, 2005; Carmichael, 2003;

Milevsky, et al., 2005; Clark, Salo and Hebb, 2005; Yaron, 2001, 2003 and 2004).

It is clear from these findings that more training tailored to meet the needs of labor trustees and emphasize and support a labor agenda will increase their levels of participation on the board and also make them better advocates for labor goals and objectives. This enrichment of the educational tools carries a variety of implications. Enhanced cooperation among unions and among education providers is necessary to share and build on the good courses and experiences already created. Appropriate amounts of time and resources need to be devoted to administering these programs and creating new programs to fill the training gaps identified in this paper.

\section{Social Networks}

Typically a labor trustee has the potential to access a large and varied network for advice or support; however, the development of these networks requires a concerted effort (Jarley, 2005). As labor trustees are most often selected or elected within the network of union hierarchy they almost invariably possess extensive connections within the labor movement. As well, where there is more than one labor trustee on the board, a network may be easier to create. Interviewees reported situations where more experienced trustees assist newer trustees or where union pension staff in trustee roles can act as mentors for those trustees who are rank and filers and have less experience with the pension or financial world or the "union world view" (PTI01; PTI17). However, this mentoring is very informal and labor trustees often have little contact with each other outside of the board meetings. As well with multi-union plans trustees do not share the same union background or perspective and may have difficulty making an immediate 
connection. An example of this is the OMERS board which has five labor trustees from five different unions.

Existing contacts outside of the union environment, particularly in the managerial and financial realms are more limited. Trust is often a serious issue for labor trustees particularly when they are new to their position. In the words of one trustee, "you are not ever sure who you can rely on, depend on, who will mentor you - who you can ask without making yourself look bad." (PTI04) It is very important that trustees locate advisors to help them understand their role and the associated jargon, rules and procedures; however, in doing so the trustee must also be careful to maintain some semblance of understanding, confidence and competence. In this environment where trustees are continually guarding their perspective and their potential weaknesses, the trust and understanding necessary to build a strong network of support is difficult to establish. A labor trustee's effort to develop relationships with other people associated with the fund is also thwarted by the pervasive sense of not-belonging, of being unwanted or unaccepted. Interviewees reported experiences of not being introduced the first time they attended meetings, of being asked for their resumes by other board members, or feeling excluded from board decisions (PTI04; PTI09; PTI11; PTI19). As a result, the process of discovering potential allies or independent sources of advice is slow and full of pitfalls. Weatherly and Tansik (1996) suggested that talking to and obtaining social support from others is important in overcoming the role ambiguity that labor trustees face (discussed in more detail below). As one trustee stated, "A strong network with other trustees and pension plans helps to increase comfort levels for trustees and build confidence in decision-making at all levels." (PTI10) 
Though all interviewees indicated that a mechanism to facilitate the development of labor trustee networks would be a welcome and worthwhile endeavor, the development of successful social networks requires mechanisms for making and sustaining contact. Currently there is no listing of labor trustees on pension boards maintained by any labor organization. Labor trustees on different boards have little knowledge of or contact with trustees on other boards. Thus, there is limited opportunity for support or knowledge sharing among trustees. Jarley (2005) presents the lack of social networks within unions as a growing problem in an article proposing a social capital model to union organization. He argues for the return to grassroots forms of internal organization that center around worker networks to revitalize and reconnect the union membership. He writes that "such workers tend to be disconnected from one another and because of their disconnectedness, lack the resources necessary to organize on their own." (Jarley, 2005: 20) This argument can be extended beyond the internal organization of individual unions and applied to the diffuse relations among labor trustees across unions. Individual trustee or union resources can be pooled and magnified through an organized network. As labour trustees operate largely in isolation across Canada it may be necessary to develop multi-tiered networks (i.e., with trustees on the same board, with trustees in the same city, with trustees in the same union and then, ideally, with trustees across unions, across the country, and internationally). Though the possibilities are almost endless, the maintenance of these networks could involve more regular and formalized meetings of labour trustees, the development of online resources, or communiqués, newsletters or bulletins catering to labour trustees.

\section{Union/Labor Agenda}

If this paper were focused on demarcating the steps to become an effective pension trustee we could perhaps stop now. However, beyond formal recruitment and selection, 
sufficient training and accessible social networks, it could be argued that a labor trustee on the pension board must receive clear directives from the union to be an effective alternative voice. Interviewees spoke at length about their fit within the board and within their union and the trouble they experience in delimiting or maintaining their social identity. Particularly when labor representation is first achieved, there is often an 'us' versus 'them' mentality at the board (PTI09; PTI11). However, it is not always clear who is 'us' and who is 'them.' Labor trustees represent their coworkers, fund beneficiaries and their union while also sharing the board table with employer trustees and financial advisors. Thus, labor trustees likely receive feedback from each of these groups regarding their expectations of a trustee's role behaviour and performance. It would be unrealistic to assume that that the trustee will be fully aligned or sympathetic with the values of each group in making investment decisions. On the one hand, labor trustees feel isolated from the other board members due to differences in perceived and/or actual competence and their association with the union. For example, on issues of SRI or alternative investment models, the traditional financial perspective conflicts with that of pension activists and most labor activists. On the other hand, situations arise where the trustees are united in a decision that benefits plan members, but may be contrary to either the employer or the union (PTI18; PTI20). This occurs in times of surplus when unions typically advocate redistribution to plan members as an immediate benefit, employers advocate a contribution holiday, and the trustees (labor and otherwise) would advocate maintenance and reinvestment to grow the future pot (PTI02).

There are also situations where the labor trustee is simply not taken seriously regardless of their perspective. This is particularly detrimental when labor trustees are in a minority on the board or in the case of advisory committees that hold no real power. Schuller and Hyman (1984) identify barriers to information sharing and trust. They argue that a cycle of distrust could 
emerge where the upward and downward flows of information between the labor trustee(s) and the employer representatives, the labor trustee(s) and the union, or the labor trustee(s) and other pension staff and advisors are suspect and guarded. This distrust and protectionism may also develop due to the suspicion that the information channeled down through the labor trustees to fund beneficiaries (union members) or channeled up to fund managers may be abused. This distrust is highlighted in a statement made by a pension manager in Schuller and Hyman's study (1984: 64): "One disadvantage [of participation] is that it can prompt demands for more information. You get into the grey area of relation between participation and collective bargaining - they innocently ask for information in the participation context, then use it for collective bargaining." In this case the manager's suspicions were heightened by the presence of the union's pensions bargaining committee and their perceived or actual relationship with labor trustees on the pension board. The result is that what information disclosure is sanctioned as a primary duty of the labor trustee tends to focus on details of individual beneficiary concern rather than the strategic functioning of the fund or the financial reports (Schuller and Hyman, 1983b).

Some of our interviewees acknowledged these barriers to involvement and noted that it can feel like labor trustees just rubber-stamp decisions made by others (PTI19; PTI12). This relates directly to the "official or de facto exclusion [of the labor trustee] from relevant decisionmaking bodies," noted by Schuller and Hyman (1984: 63). There the potential that employer or government appointed trustees also act as rubber stamps for decisions. As mentioned earlier, the Myners Report indicated that many trustees do not have professional experience in investing and spend little time preparing before making investment decisions. The inference from this report is that some trustees may be detrimentally uncritical of the assumed expertise of actuaries or fund 
managers. Schuller and Hyman (1984: 63) refer to these effects as the 'social desirability effect' and note that it is felt by all trustees. They report that open disagreement at the board table is rare. Often the comments and proposals from both the labor and employer trustees/fund managers are constrained by "self-censorship" where proposals or comments are withheld if the anticipated response is perceived as negative. Such norms of deference may further disadvantage labor trustees because of their restricted access to and experience with high level company information and decision-making and the unavailability of training programs that target non-professional fiduciaries (U.S. Department of Labor, 2002). As such, labor trustees may be more likely to acquiesce to the advice of management and other fund advisors and not exercise the degree of independent decision-making potentially available to them (Deaton, 1989).

For many, the ambiguity and occasional duty to act like an employer (i.e., when distributing a surplus or hiring fund managers) can weaken their association with the union. One trustee makes this point with respect to the fiduciary responsibility argument. "[Fiduciary responsibility] says you will act in the best interests of the pension plan and in saying that a lot of trustees will then lose their role as a union representative." (PTI17) The trustee goes on to describe the difficulty faced when bringing forth a labor perspective within the 'old boys club' mentality of the board. "Because there is this collegial atmosphere, there tends to be less challenging and when you interject with a union perspective into that sort of milieu, if you seem too overt they can always fall back on the notion that you are not following your fiduciary responsibility." (PTI17) Some trustees also mentioned the 'wining and dining' and subtle cooption process that occurs when trustees are invited to expensive industry parties and when they are exposed to an environment of power previously closed to them (PTI02; PTI17). It is important to note, however that this process is often very intangible. Several trustees noted 
positive relationships with their employer or government counterparts and stated that they were sometimes convinced to side with the labor trustees on particular issues (PTI18; PTI20). Schuller and Hyman (1984) report that labor trustees often just act as watch dogs. Their presence and questions obligate the fund managers to provide more detailed explanations of proposals and forces them to anticipate and answer alternative questions. However they also suggest that labor trustees can take a more proactive and participatory role and propose investment alternatives and/or engage in debate over submitted proposals. Choosing one of these positions and developing a clear union agenda on the purpose of their labor trustee(s) is paramount for the success of a strong labor voice on pension issues. This overarching strategy (either within a union or within the labor movement as a whole) can then inform the development of labor-centric training programmes and the creation of networks of labor activists and other labor trustees around pension issues. This clear agenda will also likely impact the recruitment and selection process because the applicant most able to deliver on that agenda should be selected. With cohesive frameworks and clear messages at each stage of their development, the labor trustee can be expected to be better able to articulate alternative investment objectives at the board table, and thus, be a more effective voice for labor interests.

\section{Accountability}

To maintain this cohesiveness and support the strategic agenda, a stronger administrative link between the union and the labor trustee is needed. It is necessary to link the strategic planning regarding labor trustee roles and expectations to the functional stages of trustee development. Currently, there is very little answerability of labor trustees to their unions or the plan beneficiaries. Indeed, many cannot be removed by the union or by a constituency that has lost confidence because they are officially appointed by the employer or government (PTI17). 
Only one trustee in our sample mentioned any sort of assessment process and it was at the board level. In his case all trustees undergo an annual self-assessment and interview by the board chair, the results of which are discussed at the board table (PTI05). One issue that arises here is the extent to which a union may want to maintain a close rein on the trustee. This would depend on the strategy that a union may adopt for its control of pension funds. If the union wants a purely fiduciary monitoring role for itself then it does not need to set up tight accountability controls on its trustee. Fiduciary duty is well-defined in statutes and pension regulations. On the other hand if the union wants to use, for example, proxy voting at selected firms to send a message to employers then it needs an accountability regime in which the trustee would work closely and meet frequently with union leadership to develop strategies for proxy voting.

As well, though unions have fought for labor representation through legislation or collective bargaining, the issues of pension governance do not seem to be a top priority. Trustees commented that the union is "not interested in training workers to become mini-capitalists" (PTI01), that the union only shows interest when there is a surplus or controversy (PTI02; PTI09; PTI17), and that there is a lack of institutional union support for trustees (PTI05; PTI06). One interviewee said that he was not required to report to the union on pension matters, but he would always scan the material received at meetings and send it to the union. He never received feedback and was convinced that no one even read the material that he had sent (PTI12). It appears that reporting structures that do exist between labor trustees and unions are informal, ad hoc and largely initiated by the trustee.

In conjunction with the devotion of resources to the creation and support of labor-centric pension education, unions need to re-evaluate their position on pension issues and commit to the support of their labor trustees. Structures which link trustees to their unions for accountability, 
direction, and support are largely absent, but trustees do want them and feel that they would benefit from the connection. The lack of pension issues as a union priority erodes the connection between the trustee and the union and therefore the development of a labor agenda on pension matters. The establishment of a pension priority and links between trustees and their unions will necessitate the creation of new administrative structures, feedback loops and the commitment to bring a clear union agenda to the pension board table.

\section{A Framework for Labor Trustee Effectiveness}

As noted earlier in the paper, many of the challenges faced by unions as they involve themselves in pension governance are similar to those faced by unions who attempt to expand their role in governance and management more broadly. Union members involved in management decision-making more broadly have faced many of the same experiences as the labor trustees interviewed for this research. Some key similarities include: the tension associated with labor participants slowing down decision-making; the lack of time for caucusing among labor participants before or during meetings; the lack of before meetings to gain additional knowledge; the feeling of not belonging; the inconsistency of selection methods and the paucity of accountability mechanisms; the lack of a clear union agenda regarding expected behaviours and desired outcomes; and the need for more union resources (time and money) to be devoted to the participatory process (Eaton and Rubinstein, 2006).

As an aid to addressing and overcoming these challenges, we develop a model that codifies the important components and stages of labor participation in pension governance and more general participation in management decisions. The model links the external constraints within which the trustee must operate (personal, board and job characteristics), the functional 
processes of trustee development (recruitment and selection, training and development of social networks, and levels of integration and participation on the board), and unions' strategic choices in defining trustee roles (union agenda and accountability structures). This model is depicted in Figure 1. Though we did not explicitly study trustee effectiveness in this research, we propose that labor trustees will be more effective members of the pension plan board of trustees if they arrive at the table with a clearly defined role, a well articulated purpose, and sufficient support through training and social networks. Future research on a larger and more quantitative scale is necessary to test this hypothesis.

Throughout this research, we have advocated for a stakeholder approach toward union involvement in pension governance; however, this model recognizes that some unions may choose to take a more conservative approach. The implication here is that the resources committed to trustee support and development will be different depending on the strategic choices and goals of the union. Regardless of those specific goals, trustee development should be aligned with union strategy through appropriate accountability systems to maximize the trustee's ability to carry out those goals.

In many ways this model follows the methodology used in human resource management in organizations. Candidates are first recruited based on a job description that is posted to attract applicants and then the best person for the job is selected from a qualified pool by assessing potential performance on specific job-related criteria. After selection the successful candidate begins the job and undergoes orientation and training to give them the skills needed for successful performance on the job. During this period the new hire will develop formal and informal social networks with colleagues, supervisors and external contacts. They also begin to draw on the social networks they have previously developed to help them cope with the demands 
of the new job. Following these steps, the new hire reaches a stage where they have achieved a certain mastery of the characteristics of the job and are integrated and participating members of the organization. Decisions and actions at each of these stages are influenced by the organization's strategic plan and vision and this link is reinforced by systems of accountability such as performance reviews and regular feedback meetings. The personal characteristics that an individual brings to the job, the nature and description of the job itself and the characteristics of the workplace also act to influence each of these stages. If these steps are followed faithfully, the process is predicted to yield positive outcomes such as effectiveness performance on the job and worker satisfaction.

For unions, which are political organizations, the human resource management sequence of recruitment, selection, training and performance review, etc., may prove to be too linear and inorganic. Unions need to develop leaders who can represent their constituency and mobilize resources to achieve their goals through the exercise of power. This process is often idiosyncratic and organic. It is hard to predict who will emerge as a leader and one can not apply simple processes of human resource management to identify union leaders. Hence, it would be unrealistic to suggest that the political model used by unions should be cast aside to make room for a more systematic approach to finding labor trustees. However, the findings of this study suggest that there is room to blend the best features of the human resource management approach with that of the political approach to identifying leaders within the labor movement. Trustees interviewed for this study have indicated fairly unambiguously that better training, accountability and a clearly identified mandate would go a long way in making them more effective in their roles on pension boards. There is no reason why these activities would be incompatible with political processes within the union. On the contrary, once the steps outlined in our model have 
been widely disseminated as union policy, it is entirely likely that individuals aspiring to political leadership within the union will begin to acquire skills and experience that will make them suitable candidates for the pension trustee role. Thus, both mandates, political and organizational effectiveness, can be achieved if findings of this study were to be addressed in future selection, training and performance of labor trustees.

\section{Conclusions}

In general, the trustees that we interviewed entered their roles with strong social networks within their own union, had benefited from union support and other organizational resources in their past roles as union officials and had gained important experience and knowledge as a result of those union activities. They were confident, excellent communicators and were motivated to learn. As well, they entered their role with strong union identities and values. Each of these characteristics aids them as they navigate the intricacies of the pension board. However, this study helps us identify five areas that hinder the integration and participation of labor trustees on the board. Though not described or measured in this study, it is likely that labor trustees who are not integrated on the board and have decreased participation levels will be less effective in the role of pension trustee. Further research is necessary to corroborate this inference. Of the five areas of weakness, the first is that selection procedures are typically not tied to competencies or qualifications that are based upon the job description, characteristics or purpose of the labor trustee role. Second, and in the same vein, new labor trustees have limited prior experience with pensions or financial matters. Third, the knowledge and ability acquisition mechanisms that exist are often inadequate for labor trustees. They lack adequate levels of formal training (particularly that which elucidates a labor perspective) and they have limited social networks 
with labor trustees outside of their union, with their employer or government counterparts and with members of the financial community. Fourth, most trustees do not have a clear structure of accountability that outlines their individual responsibilities to the union and the union constituency. Lastly and perhaps most importantly, most unions have not developed a strategic plan for their labor trustees and the labor movement has not developed an agenda for their role in pension governance.

The implication of these findings is that token labor representation will not democratize the control of pension funds. Without training, support and a strong agenda toward alternative investing on social, ethical and environmental grounds labor trustees will be isolated by their perceived conflicts of interest and held to firm lines of fiduciary responsibility. Even the CAW, arguably the strongest critic against union involvement in pension governance, has labor trustees on some plans (i.e., Air Canada, CP Rail, VIA Rail) and must make practical decisions about their purpose and their support. If individual unions and the labor movement as a whole can agree to and actively support a mandate on pension fund involvement and labor representation they can produce labor trustees who can influence investment strategies on their own boards, they can form coalitions with other pension activists and progressive investors, and they can lobby for pension and investment reform with a single, much stronger, voice. This paper also adds to the general literature on union participation in governance and management. As previous studies have shown, unions cannot embark on such involvement lightly. Such decisions alter the relationships between unions and management, between unions and their membership and among the greater labor community. They change expectations and set new standards (Rubinstein, 2001). Unions, and in the case of pension governance, their trustees will more 
easily navigate this new ground if they enter with an agreed upon plan of action and tangible expected outcomes.

\section{Future Research}

A final implication of this research is the application of this model beyond the Canadian context. Despite differences in pension regulation and structure across Canada, labor trustees experience very similar situations on pension boards and face similar challenges. As well, unions face similar struggles regarding their positions as social, economic and political actors. As such, the model developed here could be applied to labour trustees in other countries despite differences in overarching institutional frameworks.

This study is an important first step in examining the experiences of labor trustees on pension boards, but more research is necessary to develop a broader view and to verify the model presented. Though the interviews conducted were quite informative they are a small set of views and also over-represent Ontario-based public sector pension plans. To gain access to a larger sample of trustees from public and private pension plans across the country a large sample survey is needed. Such a survey can better assess whether our findings in this study generalize to the population of labor trustees at large. 


\section{References}

Ambachtsheer, Jane. 2005. Socially responsible investing. Benefits and Compensation International 35, no. 1: 36-43.

Anand, Vineeta. 2000. U.S. pension assets cross \$10 trillion. Pensions and Investments, March 20 2000, 46.

BenefitsLink. 2006. ERISA in the United States Code.

http://benefitslink.com/erisa/crossreference.html (accessed October 2006).

Bennett, James T. and Manuel H. Johnson. 1981. Union use of employee pension funds: Introduction and overview. Journal of Labor Research 2, no. 2: 181-191.

CGA-Canada. 2004. Addressing the pensions dilemma in Canada. Certified General Accountants Association of Canada. http://www.cga-online.org/servlet/portal/ serve/Library/Advocacy+and+Research/CGA-Canada+Key+Areas+of+Interest/ Pensions/ca_pensions_report.pdf (accessed May 2005).

CLBC. 2001. Capital that works! Pension funds and alternative strategies for investing in the economy. http://www.clbc.ca/research_and_reports/archive/archive07020101.asp (accessed October, 2006).

CUPE. 1996. Pension plan governance: A review of several models. Policy Paper, November 9. http://www.cupe.ca/ pensions/pensiongovernance (accessed January, 2006).

CUPE. 2005. Why we need joint trusteeship of our pension plans. Policy Paper, Octobber 25. http://www.cupe.ca/pensions/Why_We_Need_Joint_Tr (accessed January, 2006)

Carmichael, Isla. 1998. A survey of union pension trustees. Toronto: Canadian Labor Market and Productivity Centre and Ontario Public Service Employees Union.

Carmichael, Isla. 2003. Fiduciary responsibility: A tool to control workers or an opportunity to build community wealth? In Money on the Line: Workers' Capital in Canada, edited by Isla Carmichael and Jack Quarter. Ottawa: Canadian Centre for Policy Alternatives.

Carmichael, Isla and Jack Quarter, Eds. 2003. Money on the line: Workers' capital in Canada. Toronto: Canadian Centre for Policy Alternatives.

Chapman, Peter. 2001. Labour rights shareholder resolutions draw wide support. Pension News (Canadian Labour Congress). no. 2: 9.

Clark, Gordon L. 2000. Pension fund capitalism. Oxford: Oxford University Press. 
Clark, Gordon L., James Salo and Tessa Hebb. 2005. Shareholder activism in the public spotlight: Social investors' resolutions at US corporate annual general meetings, 20012004. http://www.pensionsatwork.ca/english/pdfs/clark_wpg06_02.pdf (accessed October, 2005).

Deaton, Richard Lee. 1989. The political economy of pensions: Power, politics and social change in Canada, Britain and the United States. Vancouver: University of British Columbia Press.

Drucker, Peter. 1976. The unseen revolution: How pension fund socialism came to America. New York: Harper and Row.

Eaton, Adrienne E. and Saul A. Rubinstein. 2006. Tracking local unions involved in managerial decision-making. Labor Studies Journal 31, no. 2: 1-29

Eaton, Adrienne E., and Susan J. Schurman. 1996. Labor and workplace democracy: Past, present and future. Labor Studies Journal 21, no. 2: 3-26.

Falconer, Kirk. 1999. Prudence, patience and jobs: Pension investment in a changing Canadian economy. Ottawa: Canadian Labor Market and Productivity Centre.

Freshfields Bruckhaus Deringer. 2005. A legal framework for the integration of environmental, social and governance issues into institutional investment. Geneva, Switzerland: Asset Management Working Group, United Nations Environmental Programme Finance Initiative.

Fung, Archon., Tessa Hebb and Joel Rogers, Eds. 2001. Working capital: The power of labor's pensions. Ithaca, NY: Cornell University Press.

Ghilarducci, Teresa. 1992. Labor's capital: The economics and politics of private pensions. Boston: MIT Press.

Glaser, Barney and Anselm Strauss. 1967. The discovery of grounded theory: Strategies for qualitative research. Chicago: Aldine.

Grayson, David and Adrian Hodges. 2002. Everybody's business: Managing risk and opportunity in today's global society. New York: DK Publishing.

Greenan, Jennifer. 2003. The handbook of Canadian pension and benefit plans. 12th ed. Toronto: CCH Canadian Limited.

Gribben, Chris and Adam Faruk. 2004. Will UK pension funds become more responsible? A survey of trustees. London: Just Pensions and UK Social Investment Forum. 
Gribben, Chris and Leon Olsen. 2002. Will UK pension funds become more responsible? A survey of member nominated trustees. London: Just Pensions and UK Social Investment Forum.

Hannah, Jo-Ann. 2003. Remarks to the IQPC Canada conference: Pension investment \& governance. 28 October, in Toronto, ON. Received from author.

Hebb, Tessa and Edward T. Jackson. 2002. Pension fund investment and global capital: Labour's new agenda in trustee education in Canada. Presented at the Joint International Industrial Relations Association/Canadian Industrial Relations Association Conference, 25-28 June in Toronto, ON. Manuscript provided by author.

Hess, David. 2005. Protecting and politicizing public pension fund assets: Empirical evidence on the effects of governance structures and practice. U.C. Davis Law Review 39, no. 1: 187224.

Jarley, Paul. 2005. Unions as social capital: Renewal through a return to the logic of mutual aid? Labor Studies Journal 29, no. 4: 1-26.

Johnson, Paul, Edwin Harwood, and Dan Heldman. 1981. Unions, pensions, and financial responsibility: The British experience. Journal of Labor Research 2, no. 2: 289-309.

Katz, Harry. 1988. Policy debates over work reorganization in North American unions. In New Technology and Industrial Relations, edited by Hyman and Streeck. Oxford: Basil Blackwell.

MacDuffie, John Paul. 1995. Workers' roles in lean production: The implications for worker representation. In Lean Work: Empowerment and Exploitation in the Global Auto Industry, edited by Steve Babson. Detroit: Wayne State University Press.

Manley, Kathryn, Tessa Hebb and Ted Jackson. 2005. Targeted investing: Financial and collateral impacts. http://www.pensionsatwork.ca/english/pdfs/TargetedInvesting.pdf (accessed October, 2005).

Milevsky, Moshe, Andrew Aziz, Al Goss, Jane Comeault, and David Wheeler. 2006. Cleaning a passive index. Journal of Portfolio Management 32, no. 3: 110-120.

Myners, Paul. 2001. Institutional investment in the United Kingdom: A review. http://www.hmtreasury.gov.uk/media/2F9/02/31.pdf (accessed October, 2006).

Northrup, James P., Herbert R. Northrup, Don Bellante, and John Raisian. 1981. Union divergent investing of pensions: A power, non-employee relations issue. Journal of Labor Research 2, No. 2: 191-219.

Ontario Teachers'. 2004. Board of directors. http://www.otpp.com/web/website.nsf/web/ BoardofDirectors (accessed November 2004). 
PAW. 2004. Pensions at work: Social investment of pension funds university-union research alliance. http://www.pensionsatwork.ca.

Parker, Mike, and Jane Slaughter. 1988. Choosing sides: Unions and the team concept. Boston: South End Press.

Post, Erna. 2005. Remarks at Pensions at Work conference. Toronto, ON: October 14. See: http://www.pensionsatwork.ca/english/conference_05.php

Quarter, Jack. 1995. Crossing the line: Unionized employee ownership and investment funds. Toronto: James Lorimer and Co. Ltd.

Quarter, Jack, Isla Carmichael, Jorge Sousa, and Susan Elgie. 2001. Social investment by unionbased pension funds and labour-sponsored investment funds in Canada. Relations Industrielles/Industrial Relations 56, no. 1: 92-115.

Rubinstein, Saul, A. 2001. The local union revisited: New voices from the front lines. Industrial Relations 40, no. 3: 405-435.

SHARE. 2004. Trustee education. http://www.share.ca (accessed December 2004).

Schuller, Tom and Jeff Hyman. 1983a. Pensions: The voluntary growth of participation. Industrial Relations Journal 14, no. 1: 70-79.

Schuller, Tom and Jeff Hyman. 1983b. Information, participation and pensions: Strategyand employee-related issues. Personnel Review 12, no. 3: 26-30.

Schuller, Tom and Jeff Hyman. 1984. Forms of ownership and control: Decision-making within a financial institution. Sociology 18, no. 1: 51-70.

Stanford, Jim. 1999. Paper boom: Why real prosperity requires a new approach to Canada's economy. Toronto and Ottawa: James Lorimer and Co. Ltd. and Canadian Centre for Policy Alternatives.

Statistics Canada. 2003. Quarterly estimates of trusteed pension funds: Third quarter. Ottawa: Queen's Printer.

Thomson, Jane and David Wheeler. 2004. Human capital based investment criteria for total shareholder returns: A Canadian and International perspective. http://www.pensionsatwork .ca/english/pdfs/thomson_wheeler_human.pdf (accessed October, 2005).

US Department of Labor. 2002. Report of the working group on fiduciary education and training. http://www.dol.gov/ebsa/publications/AC_1108b02_report.html (accessed October, 2006). 
Weatherly, Kristopher A. and David A. Tansik. 1993. Tactics used by customer-contact workers: Effects of role stress, boundary spanning and control. International Journal of Service Industry Management 4, no. 3: 4-18.

Weststar, Johanna and Anil Verma. Forthcoming. Just having it is not enough: Labour's voice on pension boards. In Socially Responsible Investment of Union-Based Pension Funds, edited by Jack Quarter, Isla Carmichael and Sherida Ryan. Toronto, ON: University of Toronto Press.

Wheeler, Hoyt. 2004. Producers of the world unite! A return of reformist unionism? Labor Studies Journal 29, no. 3: 81-100.

Yaron, Gil. 2001. The responsible pension trustee: Reinterpreting the duties of prudence and loyalty in the context of socially responsible investment. Estates, Trusts and Pensions Journal 20, no. 4: 305-388.

Yaron, Gil. 2003. Fiduciary duty and the responsible trustee. http://www.share.ca/files/pdfs/ FiduciaryDuty.pdf (accessed December 2004).

Yaron, Gil. 2004. The fiduciary obligation of pension trustees to vote proxies and participate in corporate engagement. Presented at the Pensions at Work Conference. 16-17 October in Winnipeg, MB. See also http://www.pensionsatwork.ca/english/lecture_archive.php. 
Table 1: Administrative Structures of Canadian Pension Plans

\begin{tabular}{|c|c|c|c|c|}
\hline & Representative Composition & $\begin{array}{c}\text { Labor Representative } \\
\text { Selection }\end{array}$ & Example & Key Plan Characteristics \\
\hline 1 & $\begin{array}{l}\text { - } \text { sole union trusteeship } \\
\text { - plan administered by a financial } \\
\text { institution }\end{array}$ & $\begin{array}{l}\text { - elected by plan participants } \\
\text { appointed by the union }\end{array}$ & $\begin{array}{l}\text { - Marine and Shipbuilders Pension } \\
\text { Plan Local } 506 \text { British Columbia } \\
\text { - Carpentry Workers Pension Plan of } \\
\text { British Columbia }\end{array}$ & $\begin{array}{l}\text { - single union } \\
\text { - multiple employers }\end{array}$ \\
\hline 2 & $\begin{array}{l}\text { - co-sponsored by union and } \\
\text { government } \\
\text { - joint-trusteeship } \\
\text { - rotating Chair }\end{array}$ & $\begin{array}{l}\text { - elected or selected by union/plan } \\
\text { members }\end{array}$ & $\begin{array}{l}\text { - Ontario Public Service Employees' } \\
\text { Union (OPSEU) Pension Trust }\end{array}$ & 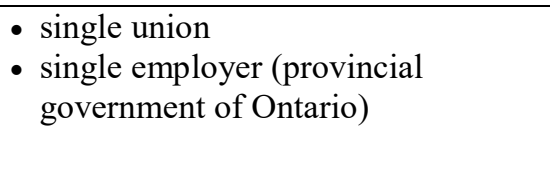 \\
\hline \multirow[t]{3}{*}{3} & \multirow[t]{3}{*}{$\begin{array}{l}\text { - equal representation } \\
\text { - rotating Chair }\end{array}$} & \multirow[t]{2}{*}{$\begin{array}{l}\text { - elected or selected by union/plan } \\
\text { members }\end{array}$} & $\begin{array}{l}\text { - Hospitals of Ontario Occupational } \\
\text { Pension Plan }\end{array}$ & $\begin{array}{l}\text { - multiple unions (Canadian Union of } \\
\text { Public Employees (CUPE), Service } \\
\text { Employees International Union, } \\
\text { Ontario Nurses' Association, } \\
\text { OPSEU) } \\
\text { - multiple employers }\end{array}$ \\
\hline & & & $\begin{array}{l}\text { - Colleges of Applied Arts and } \\
\text { Technology of Ontario Pension Plan } \\
\text { - }\end{array}$ & $\begin{array}{l}\text { - single union (OPSEU) } \\
\text { - multiple employers }\end{array}$ \\
\hline & & $\begin{array}{l}\text { - employee representatives appointed } \\
\text { by government (often on } \\
\text { recommendations by union) }\end{array}$ & $\begin{array}{l}\text { - Ontario Municipal Employees' } \\
\text { Retirement System (OMERS) } \\
\text { - }\end{array}$ & $\begin{array}{l}\text { - multiple unions (CUPE, } \\
\text { International Brotherhood of } \\
\text { Electrical Workers, Firefighters } \\
\text { Association, Police Association) } \\
\text { - single employer }\end{array}$ \\
\hline 4 & $\begin{array}{l}\text { - equal representation } \\
\text { - rotating Chair }\end{array}$ & $\begin{array}{l}\text { - union recommends representatives to } \\
\text { government }\end{array}$ & $\begin{array}{l}\text { - Alberta Public Service Pension Plan } \\
\text { - }\end{array}$ & $\begin{array}{l}\text { - single union (Alberta Union of } \\
\text { Public Employees) } \\
\text { - single employer (government of } \\
\text { Alberta) }\end{array}$ \\
\hline 5 & $\begin{array}{l}\text { - equal representation for union and } \\
\text { employer sponsors } \\
\text { - independent Chair }\end{array}$ & $\begin{array}{l}\text { - sponsoring union selects its own } \\
\text { representatives (often from } \\
\text { business/financial community) }\end{array}$ & - Ontario Teachers' Pension Plan & $\begin{array}{l}\text { - single union (Ontario Teachers' } \\
\text { Federation) } \\
\text { - single employer (Government of } \\
\text { Ontario) } \\
\end{array}$ \\
\hline 6 & $\begin{array}{l}\text { - equal representation } \\
\text { - employer Chair (extra employer rep) }\end{array}$ & $\begin{array}{l}\text { - union recommends representatives to } \\
\text { employer (one from English unions, }\end{array}$ & $\begin{array}{l}\text { - Canadian Broadcasting Corporation } \\
\text { (CBC) Pension Plan }\end{array}$ & $\begin{array}{l}\text { - multiple unions/associations } \\
\text { - single employer (CBC) }\end{array}$ \\
\hline
\end{tabular}




\begin{tabular}{|c|c|c|c|c|}
\hline & & $\begin{array}{l}\text { one from French unions and one } \\
\text { from Pensioners Association }\end{array}$ & $\bullet$ & \\
\hline 7 & $\begin{array}{l}\text { - legislated representation for union } \\
\text { and employer } \\
\text { - not necessarily equal }\end{array}$ & $\begin{array}{l}\text { - elected or selected by union/plan } \\
\text { members }\end{array}$ & - all Pension Plans in Québec & $\begin{array}{l}\text { - mixture of single-multiple union and } \\
\text { single-multiple employer depending } \\
\text { on plan }\end{array}$ \\
\hline 8 & $\begin{array}{l}\text { - advisory committee with equal } \\
\text { representation } \\
\text { - government/employer sole trustee }\end{array}$ & - elected by plan members & - Canadian Pacific Rail Pension Plan & $\begin{array}{l}\text { - multiple unions } \\
\text { - single employer }\end{array}$ \\
\hline 9 & $\begin{array}{l}\text { - advisory committee with equal } \\
\text { representation } \\
\text { - government sole trustee (Minister of } \\
\text { Finance) }\end{array}$ & $\begin{array}{l}\text { - union recommends representatives to } \\
\text { government }\end{array}$ & $\begin{array}{l}\text { - Nova Scotia Public Service } \\
\text { Superannuation Plan }\end{array}$ & $\begin{array}{l}\text { - multiple unions (NSGEU, CUPE) } \\
\text { - single employer (Government of } \\
\text { Nova Scotia) }\end{array}$ \\
\hline 10 & $\begin{array}{l}\text { - little or no union representation } \\
\text { - unions aspire to more equal role }\end{array}$ & & - Hydro One & $\begin{array}{l}\text { - multiple unions } \\
\text { - single employer }\end{array}$ \\
\hline 11 & - no union representation & & - General Motors Canada & $\begin{array}{l}\text { - single union (CAW) } \\
\text { - single employer }\end{array}$ \\
\hline
\end{tabular}

Adapted from Carmichael, 1998 with additions from CUPE, 1996; Greenan, 2003; PTI19; PTI12. 


\section{Figure 1: Model of Effective Labor Representation on Pension Boards}

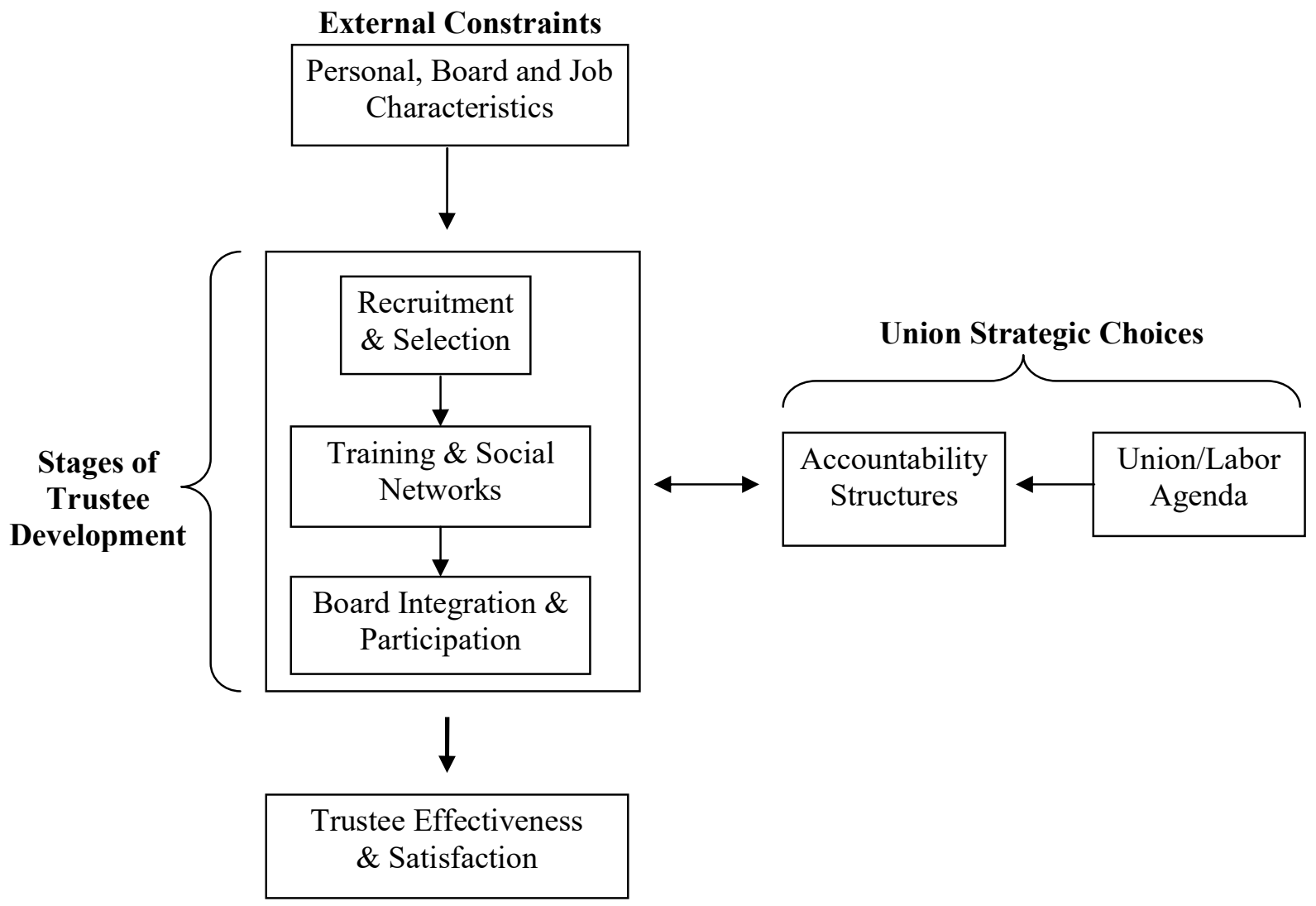




\section{Appendix 1: Questions for Interviews with Labor Trustees}

1. How long have you been in the labour force?

How long have you been a member of your union?

How long have you been a pension trustee?

What is your current job?

2. How did you become a pension trustee?

3. When you first became a pension trustee, how much experience did you have dealing with pension funds?

What previous training or experience did you find had prepared you for your role as a pension trustee?

In what areas did you find your background to be lacking in terms of doing your job as a pension trustee?

4. When you first became a pension trustee, who did you turn to for advice or support in your role? Who do you turn to now? [i.e. other trustees, union staff, pension staff, other sources] How many times do you meet in a year? Do you think you are prepared for meetings? How much material do you receive? How do you handle getting up to speed on the material?

5. Does information flow well between trustees? Between fund advisors and/or staff and trustees? Between union trustees and the union? Between trustees and members of the plan? Is this flow of information adequate for you in order to do your job? Does it help or hinder you in any way?

If you do not understand something, do you feel free to ask questions? If you need further information, do you feel free to request it?

6. Since becoming a trustee have you received any formal training, orientation or other programmes/courses for union trustees?

If yes: What type of programme was it and did you find it helpful?

If you were to take more (or any) formal training to prepare you for this job what would it be?

7. What are your responsibilities as a union trustee compared to the other trustees?

Do you experience a conflict in your role as a union member and your role as a trustee? Can you give some examples of times when you experienced this conflict and how you handled it?

8. How would you characterize the relationship between union trustees and fund managers and/or pension fund staff?

How would you characterize the relationship between employer trustees and fund managers and/or pension fund staff?

Does your relationship with 1) your union and 2) your employer 3) pension staff and other trustees impact your ability to do your job as a trustee? 
Does the union-management relationship at your workplace impact your ability to do your job as a trustee?

9. Do you like doing your job as a pension board trustee? Would you like to be re-appointed? How do you accommodate the demands of your trustee position with your regular job and/or your union work?

Are there mechanisms that you use or things that you do to make your job as a trustee easier, more manageable, less conflicting, etc.?

10. Based on your experience and knowledge of pension boards and trustees, how should pension funds go about selecting people to be union trustees? 
Appendix 2: Profile of Interviewed Labor Trustees

\begin{tabular}{lcccccc}
\hline ID & Gender & $\begin{array}{c}\text { Visible } \\
\text { Minority }\end{array}$ & $\begin{array}{c}\text { Age Bracket } \\
\text { (yrs })\end{array}$ & $\begin{array}{c}\text { Tenure on } \\
\text { Board }(\text { yrs })\end{array}$ & $\begin{array}{c}\text { Fund } \\
\text { Jurisdiction }\end{array}$ & Fund Sector \\
\hline PTI01 & M & No & $35-39$ & $4-9$ & Ontario & Public \\
PTI02 & M & No & $55-59$ & 3 or less & Ontario & Public \\
PTI03 & M & No & $50-54$ & $4-9$ & Atlantic & Private \\
PTI04 & F & No & $55-59$ & 3 or less & National & Public \\
PTI05 & M & Yes & $40-44$ & 3 or less & Western & Public \\
PTI06 & M & No & $55-59$ & 10 or more & National & Private \\
PTI07 & M & No & $45-49$ & $4-9$ & Atlantic & Private \\
PTI08 & M & No & $55-59$ & 3 or less & Western & Public \\
PTI09 & M & No & $50-54$ & 3 or less & Atlantic & Public \\
PTI10 & M & No & $35-39$ & 3 or less & Western & Public \\
PTI11 & F & No & $50-54$ & 3 or less & Atlantic & Public \\
PTI12 & M & No & $50-54$ & 3 or less & National & Private \\
PTI13 & F & No & $55-59$ & $4-9$ & Western & Public \\
PTI14 & M & No & $40-44$ & $4-9$ & Ontario & Public \\
PTI15 & M & No & $35-39$ & 3 or less & Western & Public \\
PTI16 & M & No & $45-49$ & 3 or less & Western & Public \\
PTI17 & M & Yes & $45-49$ & $4-9$ & Ontario & Public \\
PTI18 & M & No & $50-54$ & 10 or more & Western & Private \\
PTI19 & M & No & $55-59$ & 10 or more & Quebec & Private \\
PTI20 & F & No & $50-54$ & $4-9$ & Western & Public \\
\hline
\end{tabular}

